\title{
How (and What) Political Theorists Teach: Results of a National Survey
}

\author{
MATTHEW J. MOORE
}

Cal Poly State University

\begin{abstract}
The article reports the results of a 2008 national survey of political theorists concerning what and how they teach. The results are based on 1,086 responses from professors at accredited, four-year colleges and universities in the United States. The responses include information about which thinkers are currently being taught, the status of non-Western political thought in political theory education, the relative degrees of implementation of various teaching methodologies, demographic information about the respondents, information about the kinds of texts theorists use to teach, and finally a ranking of undergraduate programs in terms of their strength in theory.
\end{abstract}

\section{Introduction ${ }^{1}$}

During the fall of 2008, I conducted a survey of political theorists teaching in the United States. The survey asked a wide range of questions about the role of political theory within the broader discipline of political science, the backgrounds and experiences of the people who are currently teaching political theory classes, and finally about how (and what) political theorists teach. This article reports the findings regarding teaching. ${ }^{2}$

My hope is that the study will be helpful in two different ways. First, I hope that it will shed some light on the current status of political theory within political science. Debates and discussions about the role and fate of theory have been going on for more than 50 years and seem likely to continue. ${ }^{3}$ I believe that having some empirical evidence - about who theorists are, what they teach, and what their experiences within the profession have been-will be helpful in those discussions. ${ }^{4}$ Second, although there has been a lot of research on teaching and learning within political science over the past 20 or so years, much of it has been based on case studies or small- $N$ surveys. This survey received 1,086 responses total, with most questions getting 700-800 responses. Thus, I believe that the findings of the survey may be of interest to political scientists generally, for the light they shed on pedagogy in political science today. However, because of the broad range of questions posed by the survey, each topic was covered by only one or two questions. Thus, rather than 
making a large contribution to any one ongoing discussion regarding political science pedagogy, my hope is that the results are able to make small contributions to several conversations about teaching and learning.

\section{Overview of the Survey}

My goal was to attempt to survey every political theorist in the political science (or cognate $^{5}$ ) department of every accredited, four-year college and university in the United States. ${ }^{6}$ My research assistants ${ }^{7}$ and I used two methods to identify participants: First, we attempted to find and visit the webpage of every such department ${ }^{8}$ and then to identify the people who appeared to have a teaching or research interest in political theory ${ }^{9}$; second, we included everyone in the American Political Science Association's (APSA) Directory of Political Science Faculty and Programs, 2007-2008 (APSA 2007) who listed an interest in political theory (not including Positive Political Theory). ${ }^{10}$ Anyone who could not be ruled out was included.

We evaluated 2,073 schools. Ultimately, I sent 5,144 invitations to individuals, ${ }^{11}$ roughly half to people I had reason to believe were political theorists and roughly half to people I couldn't rule out. ${ }^{12}$ Of those invitations, 435 resulted in bounced e-mails or returned letters, which means that 4,709 apparently reached the invitees. From that group, 358 individuals identified themselves as either not being political theorists or no longer teaching in the U.S., ${ }^{13}$ so the total number of invitations received by (apparently) eligible recipients was 4,351 .

By the time data collection closed, 1,086 individuals had completed some or all of the online survey. Thus the simple response rate (total responses/total invitations received by eligible respondents) was $1,086 / 4,351$ or $25 \%$. The response rate among people we now have reason to believe are political theorists and who received the invitation was $1,086 / 2,203$ or $49.3 \% .^{14}$

\section{Who Theorists Are}

One initial question of interest is simply who political theorists are demographically. Some information about the demographics of the discipline more broadly are already available, ${ }^{15}$ and the APSA is in the process of collecting new data on demographics and academic rank. ${ }^{16}$ Table 1 shows some basic demographic information about the respondents. Where comparison information is available, I have included it. The data suggest that political theorists as a subgroup are quite similar demographically to political scientists generally, though with some notable differences. $^{17}$

Many of the data in Table 1 simply confirm what everyone already suspected, for example that having a $\mathrm{PhD}$ is almost always a requirement for getting a faculty position in political science $(98.3 \%$ of respondents either have the $\mathrm{PhD}$ in hand or are ABD), that relatively few people obtain faculty positions before they turn 30 (a point supported by the Survey of Earned Doctorates finding that the median time from start to completion of a $\mathrm{PhD}$ in political science is 9.1 years ${ }^{18}$ ), and that political theory and political science generally remain disproportionately male.

However, these data do raise three interesting questions - regarding gender, age, and academic rank - about the demographics of the subfield of political theory compared to the demographics of the discipline as a whole. First, there appears to be a higher proportion of women in political theory than in the discipline generally 
Table 1. Demographic characteristics of respondents

\begin{tabular}{|c|c|c|c|}
\hline & $\%$ & $N$ & $\begin{array}{l}\% \text { among political } \\
\text { scientists generally* }\end{array}$ \\
\hline \multicolumn{4}{|l|}{ Highest Degree } \\
\hline $\mathrm{PhD}$ or equivalent & 96.1 & 745 & \\
\hline $\mathrm{ABD}$ & 2.2 & 17 & \\
\hline MA or equivalent & 0.9 & 7 & \\
\hline $\mathrm{JD}$ & 0.7 & 5 & \\
\hline $\mathrm{BA}$ or equivalent & 0.1 & 1 & \\
\hline TOTAL & 100 & 775 & \\
\hline \multicolumn{4}{|l|}{ Age } \\
\hline under 30 & 1.5 & 12 & 5.5 \\
\hline $30-39$ & 26.4 & 204 & 25.4 \\
\hline $40-49$ & 29.7 & 230 & 27.3 \\
\hline $50-59$ & 22.4 & 173 & 29.5 \\
\hline $60-69$ & 17.7 & 137 & 11.3 \\
\hline 70 or older & 2.3 & 18 & 1.1 \\
\hline TOTAL & 100 & 774 & 100 \\
\hline \multicolumn{4}{|l|}{ Gender } \\
\hline Female & 26.6 & 205 & 23.8 \\
\hline Male & 72.9 & 562 & 76.2 \\
\hline Other & 0.5 & 4 & \\
\hline TOTAL & 100 & 771 & 100 \\
\hline \multicolumn{4}{|l|}{ Academic Rank } \\
\hline Full Professor & 36.1 & 279 & 42.0 \\
\hline Associate Professor & 27.6 & 213 & 28.4 \\
\hline Assistant Professor & 27.2 & 210 & 25.8 \\
\hline Full-Time Instructor or Lecturer & 2.3 & 18 & 2.9 \\
\hline Part-Time Instructor or Lecturer & 3.2 & 25 & \\
\hline Visiting Instructor or Professor & 1.9 & 15 & \\
\hline Emeritus/a & 1.4 & 11 & \\
\hline Other & 0.3 & 2 & 0.9 \\
\hline TOTAL & 100 & 773 & 100 \\
\hline \multicolumn{4}{|l|}{ Type of Department } \\
\hline political science/government & 81.0 & 628 & \\
\hline international relations & 0.8 & 6 & \\
\hline international affairs & 0.7 & 5 & \\
\hline political science and history & 6.7 & 52 & \\
\hline political science and geography & 0.5 & 4 & \\
\hline political science and sociology & 1.0 & 8 & \\
\hline public affairs & 0.8 & 6 & \\
\hline social sciences & 4.1 & 32 & \\
\hline liberal arts & 0.9 & 7 & \\
\hline general education & 0.8 & 6 & \\
\hline Other & 2.7 & 21 & \\
\hline TOTAL & 100 & 775 & \\
\hline
\end{tabular}

${ }^{*}$ Source: APSA Survey of Political Science Departments 2000-2001. Washington, DC: American Political Science Association, 2001. 
$(26.6 \%$ to $23.8 \%)$. Other recent survey data on the discipline suggest that this difference is real. Novkov and Barclay report unpublished data from Sedowski and Brintnall's 2007 survey of the gender composition of the membership of the APSA, which also found that political theory had a higher proportion of women than the membership as a whole, though the difference was very small $(28.9 \%$ vs. $28.8 \%$; Novkov and Barclay 2010, 105, Table 2a). While these results are not directly comparable to my results, since the two surveys draw from different pools that overlap to an unknown degree, they reinforce the finding that political theory appears to attract women more than the rest of the discipline taken as a whole. However, Sedowski and Brintnall's data also show that several other subfields have larger proportions of women than political theory does: Comparative Politics (32.7\%), Public Law (30.0\%), Public Administration (29.1\%), and Public Policy (31.7\%). Because these data only cover members of the APSA (who account for only $81.5 \%$ of the respondents to my survey), it's not possible to tell whether they accurately reflect the universe of American political scientists. The safest conclusion is that political theory does appear to attract more women than the rest of the discipline taken as a whole; though it may be that some other subfields also attract more women than the disciplinary average.

If it's genuinely the case that political theory attracts more women than political science generally, it would be interesting to know why. Since my survey questions focused primarily on descriptive demographic data, I cannot offer any direct answer to this question. However, one possible explanation is that female political scientists may be more interested than male political scientists in studying questions of gender, sexuality, gender inequality, and related issues. There is at least some indirect evidence for this interpretation elsewhere in the survey. As Martha Ackelsberg has pointed out, female respondents to the survey were much more likely than male respondents to include female and feminist thinkers on a list of political theorists whose work will still be relevant in 20 years (Ackelsberg, 2010). Thus perhaps female political scientists have found political theory to be relatively more open to such research than other subfields within the discipline. (Such a difference would be only relative, since women still make up only $26.6 \%$ of theorists.)

Novkov and Barclay's recent survey (2010) regarding lesbians, gays, bisexuals, and transgendered (LGBT) people and issues in the discipline offers some indirect support for this type of analysis. Their study reveals that political theory has the largest percentage of self-identified LGBT among the various subfields of political science (Novkov and Barclay 2010, 96, Table 2). The same study found that the subfields differed considerably in terms of their degree of acceptance of the idea that LGBT issues are an appropriate area of study for political scientists, with political theory being one of the most accepting subfields (Novkov and Barclay 2010, 101, Figure 2). Further, $67 \%$ of LGBT respondents reported studying LGBT issues in their work at least to some degree, while only $32 \%$ of heterosexual respondents reported engaging those issues (Novkov and Barclay 2010, 101, Table 13). This suggests that LGBT political scientists are more likely to study LGBT issues than heterosexual political scientists, and that they (correctly) believe that political theory is an appropriate and friendly part of the discipline to do that work in (compared to the other traditional subfields). If similar dynamics exist for female scholars, that would help to explain why there appears to be a larger proportion of women in political theory than in political science overall. In any case, that nearly $27 \%$ of theorists are women is a big change from when the last survey of political theorists was done, 
Table 2. Thinkers who should be taught more/less, ranked by total number of votes

\begin{tabular}{|c|c|c|c|c|c|}
\hline Thinker & More & More rank & Less & Less rank & Total votes \\
\hline Rawls, John & 44 & 12 & 196 & 1 & 240 \\
\hline Marx, Karl & 87 & 3 & 71 & 2 & 158 \\
\hline Plato & 94 & 1 & 35 & 8 & 129 \\
\hline Foucault, Michel & 58 & 7 & 66 & 3 & 124 \\
\hline Aristotle & 89 & 2 & 20 & 20 & 109 \\
\hline Nietzsche, Friedrich & 66 & 5 & 31 & 11 & 97 \\
\hline Locke, John & 39 & 18 & 56 & 4 & 95 \\
\hline Arendt, Hannah & 65 & 6 & 30 & 12 & 95 \\
\hline Tocqueville, Alexis de & 67 & 4 & 16 & 22 & 83 \\
\hline Hobbes, Thomas & 37 & 20 & 40 & 5 & 77 \\
\hline Augustine & 54 & 9 & 23 & 15 & 77 \\
\hline Hegel, G.W.F. & 55 & 8 & 22 & 16 & 77 \\
\hline Aquinas, Thomas & 50 & 10 & 26 & 14 & 76 \\
\hline Habermas, Jürgen & 37 & 20 & 38 & 6 & 75 \\
\hline Machiavelli, Niccolò & 47 & 11 & 21 & 19 & 68 \\
\hline Strauss, Leo & 31 & 27 & 35 & 8 & 66 \\
\hline Rousseau, Jean-Jacques & 40 & 17 & 22 & 16 & 62 \\
\hline Mill, John Stuart & 32 & 25 & 29 & 13 & 61 \\
\hline Burke, Edmund & 42 & 13 & 13 & 26 & 55 \\
\hline Kant, Immanuel & 32 & 25 & 22 & 16 & 54 \\
\hline Dewey, John & 39 & 18 & 11 & 28 & 50 \\
\hline $\begin{array}{l}\text { Montesquieu, } \\
\text { Charles-Louis de } \\
\text { Secondat, baron de La } \\
\text { Brède et de }\end{array}$ & 42 & 13 & 7 & 36 & 49 \\
\hline Cicero & 42 & 13 & 6 & 38 & 48 \\
\hline Derrida, Jacques & 10 & 62 & 37 & 7 & 47 \\
\hline Weber, Max & 41 & 16 & 3 & 56 & 44 \\
\hline Nozick, Robert & 8 & 73 & 32 & 10 & 40 \\
\hline Smith, Adam & 35 & 22 & 4 & 49 & 39 \\
\hline Hume, David & 33 & 24 & 5 & 42 & 38 \\
\hline Wollstonecraft, Mary & 35 & 22 & 0 & 100 & 35 \\
\hline Fanon, Frantz & 29 & 28 & 5 & 42 & 34 \\
\hline Butler, Judith & 17 & 40 & 16 & 22 & 33 \\
\hline Hayek, F.A. & 28 & 30 & 4 & 49 & 32 \\
\hline Thucydides & 29 & 28 & 1 & 80 & 30 \\
\hline Schmitt, Carl & 12 & 51 & 16 & 22 & 28 \\
\hline Heidegger, Martin & 15 & 43 & 13 & 26 & 28 \\
\hline Oakeshott, Michael & 27 & 32 & 1 & 80 & 28 \\
\hline Du Bois, W. E. B. & 28 & 30 & 0 & 100 & 28 \\
\hline Gramsci, Antonio & 23 & 33 & 3 & 56 & 26 \\
\hline Taylor, Charles & 14 & 46 & 11 & 28 & 25 \\
\hline Connolly, William & 13 & 49 & 11 & 28 & 24 \\
\hline
\end{tabular}


Table 2. Continued

\begin{tabular}{|c|c|c|c|c|c|}
\hline Thinker & More & More rank & Less & Less rank & Total votes \\
\hline Madison, (James?) & 21 & 36 & 3 & 56 & 24 \\
\hline Voegelin, Eric & 23 & 33 & 1 & 80 & 24 \\
\hline Rorty, Richard & 14 & 46 & 9 & 32 & 23 \\
\hline Xenophon & 23 & 33 & 0 & 100 & 23 \\
\hline Dahl, Robert & 5 & 95 & 17 & 21 & 22 \\
\hline Berlin, Isaiah & 16 & 42 & 6 & 38 & 22 \\
\hline Walzer, Michael & 19 & 37 & 3 & 56 & 22 \\
\hline Freud, Sigmund & 18 & 38 & 3 & 56 & 21 \\
\hline Young, Iris Marion & 17 & 40 & 3 & 56 & 20 \\
\hline $\begin{array}{l}\text { Spinoza, Baruch or } \\
\text { Benedict }\end{array}$ & 18 & 38 & 2 & 68 & 20 \\
\hline Sandel, Michael & 4 & 115 & 15 & 25 & 19 \\
\hline Marcuse, Herbert & 13 & 49 & 6 & 38 & 19 \\
\hline Lenin, V.I. & 6 & 86 & 11 & 28 & 17 \\
\hline Federalist Papers & 12 & 51 & 4 & 49 & 16 \\
\hline Emerson, Ralph Waldo & 12 & 51 & 3 & 56 & 15 \\
\hline Al-Farabi, Abu Nasr & 15 & 43 & 0 & 100 & 15 \\
\hline $\begin{array}{l}\text { Confucius (aka Kongfuzi, } \\
\text { Kongzi, K'ung-fu-tzu, } \\
\text { K'ung-tzu, Kongqiu, } \\
\text { Zhongzi) }\end{array}$ & 15 & 43 & 0 & 100 & 15 \\
\hline Beauvoir, Simone de & 11 & 56 & 3 & 56 & 14 \\
\hline MacIntyre, Alasdair & 11 & 56 & 3 & 56 & 14 \\
\hline Gandhi, Mohandas K. & 14 & 46 & 0 & 100 & 14 \\
\hline Wittgenstein, Ludwig & 11 & 56 & 2 & 68 & 13 \\
\hline Wolin, Sheldon & 11 & 56 & 2 & 68 & 13 \\
\hline Grotius, Hugo & 12 & 51 & 1 & 80 & 13 \\
\hline Shklar, Judith & 12 & 51 & 1 & 80 & 13 \\
\hline MacKinnon, Catharine & 7 & 81 & 5 & 42 & 12 \\
\hline Deleuze, Gilles & 9 & 66 & 3 & 56 & 12 \\
\hline Paine, Thomas & 10 & 62 & 2 & 68 & 12 \\
\hline $\begin{array}{l}\text { Dworkin, (Ronald? } \\
\text { Andrea?) }\end{array}$ & 2 & 143 & 9 & 32 & 11 \\
\hline Bacon, Francis & 11 & 56 & 0 & 100 & 11 \\
\hline Marsilius Of Padua & 11 & 56 & 0 & 100 & 11 \\
\hline Dworkin, Ronald & 2 & 143 & 8 & 34 & 10 \\
\hline Friedman, Milton & 2 & 143 & 8 & 34 & 10 \\
\hline Bentham, Jeremy & 3 & 142 & 7 & 36 & 10 \\
\hline Skinner, Quentin & 4 & 115 & 6 & 38 & 10 \\
\hline Agamben, Giorgio & 5 & 95 & 5 & 42 & 10 \\
\hline Luther, Martin & 8 & 73 & 2 & 68 & 10 \\
\hline Mills, Charles & 9 & 66 & 1 & 80 & 10 \\
\hline Christine de Pizan & 10 & 62 & 0 & 100 & 10 \\
\hline
\end{tabular}


Table 2. Continued

\begin{tabular}{|c|c|c|c|c|c|}
\hline Thinker & More & More rank & Less & Less rank & Total votes \\
\hline King, Martin Luther, Jr. & 10 & 62 & 0 & 100 & 10 \\
\hline Calvin, John & 7 & 81 & 2 & 68 & 9 \\
\hline Pateman, Carole & 8 & 73 & 1 & 80 & 9 \\
\hline Said, Edward & 8 & 73 & 1 & 80 & 9 \\
\hline Thoreau, Henry David & 8 & 73 & 1 & 80 & 9 \\
\hline Camus, Albert & 9 & 66 & 0 & 100 & 9 \\
\hline Montaigne, Michel de & 9 & 66 & 0 & 100 & 9 \\
\hline Niebuhr, Reinhold & 9 & 66 & 0 & 100 & 9 \\
\hline Rancière, Jacques & 9 & 66 & 0 & 100 & 9 \\
\hline Sen, Amartya & 9 & 66 & 0 & 100 & 9 \\
\hline Chomsky, Noam & 5 & 95 & 3 & 56 & 8 \\
\hline Baudrillard, Jean & 6 & 86 & 2 & 68 & 8 \\
\hline Green, T.H. & 7 & 81 & 1 & 80 & 8 \\
\hline Aeschylus & 8 & 73 & 0 & 100 & 8 \\
\hline Kropotkin, Peter & 8 & 73 & 0 & 100 & 8 \\
\hline Sophocles & 8 & 73 & 0 & 100 & 8 \\
\hline Kymlicka, Will & 2 & 143 & 5 & 42 & 7 \\
\hline John of Salisbury & 4 & 115 & 3 & 56 & 7 \\
\hline Lincoln, Abraham & 5 & 95 & 2 & 68 & 7 \\
\hline Nussbaum, Martha & 5 & 95 & 2 & 68 & 7 \\
\hline Benjamin, Walter & 6 & 86 & 1 & 80 & 7 \\
\hline hooks, bell & 6 & 86 & 1 & 80 & 7 \\
\hline Bourdieu, Pierre & 7 & 81 & 0 & 100 & 7 \\
\hline Dante & 7 & 81 & 0 & 100 & 7 \\
\hline Huntington, Samuel & 1 & 149 & 5 & 42 & 6 \\
\hline $\begin{array}{l}\text { Mao Zedong (aka Mao } \\
\text { Tse-Tung) }\end{array}$ & 1 & 149 & 5 & 42 & 6 \\
\hline Rand, Ayn & 2 & 143 & 4 & 49 & 6 \\
\hline Wolin, (Sheldon? Richard?) & 2 & 143 & 4 & 49 & 6 \\
\hline Benhabib, Seyla & 4 & 115 & 2 & 68 & 6 \\
\hline Durkheim, Émile & 4 & 115 & 2 & 68 & 6 \\
\hline Okin, Susan Moller & 4 & 115 & 2 & 68 & 6 \\
\hline Bodin, Jean & 5 & 95 & 1 & 80 & 6 \\
\hline Fraser, Nancy & 5 & 95 & 1 & 80 & 6 \\
\hline Popper, Karl & 5 & 95 & 1 & 80 & 6 \\
\hline Whitman, Walt & 5 & 95 & 1 & 80 & 6 \\
\hline Baldwin, James & 6 & 86 & 0 & 100 & 6 \\
\hline Goldman, Emma & 6 & 86 & 0 & 100 & 6 \\
\hline Ibn Khaldun & 6 & 86 & 0 & 100 & 6 \\
\hline James, William & 6 & 86 & 0 & 100 & 6 \\
\hline Sumner, William Graham & 6 & 86 & 0 & 100 & 6 \\
\hline Fukuyama, Francis & 1 & 149 & 4 & 49 & 5 \\
\hline Brown, Wendy & 4 & 115 & 1 & 80 & 5 \\
\hline
\end{tabular}


Table 2. Continued

\begin{tabular}{|c|c|c|c|c|c|}
\hline Thinker & More & More rank & Less & Less rank & Total votes \\
\hline Cohen, G.A. & 4 & 115 & 1 & 80 & 5 \\
\hline Descartes, René & 4 & 115 & 1 & 80 & 5 \\
\hline Elshtain, Jean & 4 & 115 & 1 & 80 & 5 \\
\hline Althusius, Johannes & 5 & 95 & 0 & 100 & 5 \\
\hline Averroës (Ibn Rushd) & 5 & 95 & 0 & 100 & 5 \\
\hline Calhoun, John C. & 5 & 95 & 0 & 100 & 5 \\
\hline Homer & 5 & 95 & 0 & 100 & 5 \\
\hline Kirk, Russell & 5 & 95 & 0 & 100 & 5 \\
\hline Maimonides, Moses & 5 & 95 & 0 & 100 & 5 \\
\hline Mohanty, Chandra Talpade & 5 & 95 & 0 & 100 & 5 \\
\hline Shakespeare, William & 5 & 95 & 0 & 100 & 5 \\
\hline Spivak, Gayatri & 5 & 95 & 0 & 100 & 5 \\
\hline The Bible & 5 & 95 & 0 & 100 & 5 \\
\hline West, Cornel & 5 & 95 & 0 & 100 & 5 \\
\hline Post-modernism & 0 & 152 & 4 & 49 & 4 \\
\hline Adams, John & 4 & 115 & 0 & 100 & 4 \\
\hline Addams, Jane & 4 & 115 & 0 & 100 & 4 \\
\hline Anzaldúa, Gloria & 4 & 115 & 0 & 100 & 4 \\
\hline Astell, Mary & 4 & 115 & 0 & 100 & 4 \\
\hline Austin, J. L. & 4 & 115 & 0 & 100 & 4 \\
\hline Berry, Wendell & 4 & 115 & 0 & 100 & 4 \\
\hline Constant, Benjamin & 4 & 115 & 0 & 100 & 4 \\
\hline Herodotus & 4 & 115 & 0 & 100 & 4 \\
\hline Hofstadter, Richard & 4 & 115 & 0 & 100 & 4 \\
\hline $\begin{array}{l}\text { Lao-tzu (aka Lao Tse, Lao } \\
\text { Tze, Lao tzu, Lao Zi, } \\
\text { Lao-tse, Laozi, Lao Tun, } \\
\text { Lao Tan, Li Erh) }\end{array}$ & 4 & 115 & 0 & 100 & 4 \\
\hline Lévinas, Emmanuel & 4 & 115 & 0 & 100 & 4 \\
\hline Luxemburg, Rosa & 4 & 115 & 0 & 100 & 4 \\
\hline More, Thomas & 4 & 115 & 0 & 100 & 4 \\
\hline Phillips, Anne & 4 & 115 & 0 & 100 & 4 \\
\hline Plutarch & 4 & 115 & 0 & 100 & 4 \\
\hline Ricoeur, Paul & 4 & 115 & 0 & 100 & 4 \\
\hline Schopenhauer, Arthur & 4 & 115 & 0 & 100 & 4 \\
\hline
\end{tabular}

Note. Only thinkers who received either four "More" votes or four "Less" votes are included in this table.

in 1977, when only $10.5 \%$ of respondents were women (Hajjar and Brzezinski 1978, 298).

A second issue of interest concerns the relatively smaller proportion of theorists under 30 in faculty positions $(1.5 \%)$ compared to the discipline as a whole $(5.5 \%)$. I'm not aware of any data from other sources that compare age and subfield, so at the moment this finding can only pose questions for future research. Logically, 
it seems that there are two likely explanations: (1) Future theorists start graduate school later than people who ultimately gain other political science faculty positions; and/or (2) future theorists take longer to complete the $\mathrm{PhD}$ than other political scientists. That the correct explanation is one (or both) of those two is supported by the fact the proportions of political theorists who are 30-39 and 40-49 are larger than the proportions in the profession generally. These three data points suggest that political theorists enter faculty positions at slightly older ages than other political scientists. It's possible that there may also be a cohort effect, since the proportion of political theorists who are 50-59 is nearly $25 \%$ smaller than the proportion of political scientists generally in that age group. However, given the different natures of the samples, and the period of time that elapsed between the two surveys, we should be very cautious about drawing any conclusions. Rather, these results are primarily suggestive and indicate the need for more research on this question.

Roughly the same holds for the finding that more theorists $(20 \%)$ are 60 or older than are political scientists generally $(12.4 \%)$. While it's certainly possible that political theorists age better professionally-perhaps because they work on topics and issues whose scholarship is relatively stable over time, so that their knowledge is less likely to become outdated, or perhaps because political theory provides unusual intrinsic rewards that encourage practitioners to stay in the field longer - it may also be true that these apparent differences are merely the products of comparing different samples. Until additional research is done to shed further light on this issue, it must remain an intriguing mystery.

The third issue of concern is the finding that fewer political theorists are full professors than are other political scientists $(36.1 \%$ vs. $42 \%)$. This is especially puzzling given the finding that political theorists tend to stay in faculty positions until later ages than nontheorists; we would expect that longer careers would lead to a higher proportion of full professors. Again, without further data we aren't able to determine the cause of this apparent promotion gap. Just speculating, it seems that one or more of the following explanations is likely: (1) that theorists are disproportionately employed at institutions with high standards for promotion to full professor, so that on average they face a higher bar than other political scientists (there is some support for this interpretation in the survey's finding that $25.5 \%$ of U.S. schools that teach any political science at all do not offer any classes in political theory, suggesting that theory faculty positions are more concentrated than other political science faculty positions); (2) that theorists in general do less and/or less rigorous work than other political scientists and, therefore, are less deserving of promotion to full professor; (3) that the work that theorists do is devalued by their peers, thus preventing them from achieving promotions that they might otherwise qualify for. (For data on the degree to which theory work is respected within the discipline see Moore (2010).) Again, further research could shed light on this question.

\section{Who Theorists Teach}

The ostensibly simple and straightforward question of which thinkers and texts political theorists teach is both difficult to investigate and fraught with complexity. On the one hand, it would be helpful for many in the subfield (notably graduate students and assistant professors) to have some idea which texts and thinkers are most widely seen in the field as important, for example to assist them in composing syllabi 
and perhaps in framing research agendas. On the other hand, merely compiling and publishing such data inevitably has the effect of reifying and normalizing what might otherwise be fluid and plural practices. Learning that many people teach Hannah Arendt may lead some people who would prefer to teach Simone Weil to decide that they should get with the program, thereby undermining a healthy breadth and idiosyncrasy within political theory. ${ }^{19}$ Further, a number of scholars over the past 20 years have argued that American political theorists should broaden the range of thinkers and texts they teach to include comparative or non-Western thinkers and traditions. ${ }^{20}$ That call might be seen as an effort to pluralize political theory, or it might be seen as an effort to construct an alternative but similarly normalizing canon.

My own perspective, which motivated this part of the survey, is that finding out what political theorists actually teach, both from the traditional, Western canon and from non-Western sources, is important enough to risk the normalizing effects that obtaining and publicizing such data are likely to have. This is especially true regarding comparative political theory; up to now, frankly, we have barely had even anecdotal data about whether theorists are teaching non-Western texts or not (though of course the data on what theorists are publishing about are readily available). Further, for those who are interested in beginning to teach non-Western texts, but whose graduate training did not expose them to enough such texts to fill a syllabus, learning what authors and texts others have had success teaching would be a helpful first step.

But discovering who political theorists teach turns out to be more difficult than it sounds. Clearly, it would have been impossible to give survey respondents a comprehensive checklist of several hundred names and to ask them to mark all the thinkers they regularly teach. No one would answer such a question, and I certainly would never have thought to include all the thinkers that respondents ultimately named. At the opposite extreme, simply asking respondents to name 1 or 5 or 10 thinkers they regularly teach would have resulted in a completely predictable recital of the canon: Hobbes, Locke, Plato, Aristotle, Mill, and so on. To avoid these two problems, I instead asked respondents to name five thinkers they think should be taught more, and five thinkers they think should be taught less. (See below for a discussion of the question format regarding non-Western thinkers.) This question format introduces the problem of essentially asking respondents to guess about what other people are teaching, but it also encourages them to name thinkers whom they think should be taught (and thus are likely teaching themselves), but who are underappreciated. It also allows respondents to identify thinkers whom they think are overrated and overrepresented. Given the indirect nature of the questions, we have to be cautious in interpreting the results. That said, they give us the best data available about whom theorists actually teach and value. Table 2 shows all the thinkers who received at least four "More" or four "Less" votes. The thinkers are ranked by the total number of votes they received, which is a rough indication of how much controversy there is within the subfield about each thinker, either because many people believe that thinker is overtaught, or many believe that the thinker is undertaught.

What do the results of Table 2 tell us? A first observation is that there is more controversy about the "canon" within political theory than we might have expected. For example, it would have been a good bet that Rawls is widely taught by political theorists, but it is revealing to see that he was the overwhelming "winner" among thinkers theorists believe should be taught less. Similarly, the field is apparently 
divided about the importance of Marx, Foucault, Habermas, Judith Butler, and Leo Strauss (all of whom had roughly similar numbers of "More" and "Less" votes), but also about Locke, Hobbes, and John Stuart Mill (who also had roughly similar numbers of "More" and "Less"). A second and related observation is that there is more pluralism in terms of what is being taught than we might have guessed. Once you get past the first 25 names in Table 2, which represent roughly the obvious traditional canon, the range of names is both large and surprising. For example, apparently a number of political theorists are teaching (and wishing that others would also teach) Fanon, Oakeshott, Xenophon, Marcuse, Al-Farabi, Confucius, and Wittgenstein. Finally, there are a number of well-known contemporary thinkers-Fukuyama, Huntington, Sandel, Nozick, Ronald Dworkin - whom few theorists would like to see taught more, and some would like to see taught less, which may be an indication of the waning of their influence (or possibly of a situation in which they are simply being taught exactly the right amount).

Table 3 summarizes the answers to a question that asked respondents to identify up to five non-Western thinkers whose work they regularly teach. One notable finding is that just over a third of respondents $(37.3 \%)$ indicated that they regularly teach any work of non-Western thinkers. Absent comparison data, it's not possible to tell whether this represents a change in the direction of internationalizing the theory curriculum, or merely the fact that many theorists were already teaching the work of non-Western thinkers. For example, a number of the thinkers listed - Gandhi, Al-Farabi, Lao-tzu, Mao, Sun-tzu, Averroës, Said, Achebe, Avicenna, Sen, Freire, and others-have been taught by political theorists (and others) for a number of years (see, for example, Strauss's work on Al-Farabi ). In either case, for those who are committed to seeing non-Western texts included more centrally in the theory curriculum, there is clearly a lot of work to do, since the vast majority of respondents do not regularly teach such work.

\section{What and Why Theorists Teach}

A number of questions in the survey asked about what theorists teach and what they hope to accomplish from teaching.

\section{Primary Texts vs. Textbooks}

There are two basic approaches to teaching political theory, especially at the introductory level: having students read primary texts, and using some kind of textbook (other than an anthology of primary sources) to give students an overview and analytical framework for understanding the concerns of political theory generally. Obviously there is a lot of room for combining the two approaches, but, at least in my own experience of looking at many political theory course descriptions and syllabi as part of the survey, it seems clear that most courses choose one path or the other. Each path has strengths and weaknesses: Courses that focus on primary texts give students the chance to engage with arguments and ideas that political theorists have found important and to encourage them to develop critical reading and analysis skills, but such courses often spend little or no time providing historical background or even a general description of the subfield, leaving it to students to piece that information together. Courses that use textbooks are able to provide an overview of the concerns and methods of political theory, as well as some kind of historical and/or analytical framework for understanding theory's approach to political and 
Table 3. Non-Western thinkers respondents report teaching regularly

\begin{tabular}{|c|c|}
\hline Votes & Theorist \\
\hline 104 & Gandhi, Mohandas K. \\
\hline 79 & $\begin{array}{l}\text { Confucius (aka Kongfuzi, Kongzi, K'ung-fu-tzu, K'ung-tzu, Kongqiu, } \\
\text { Zhongzi) }\end{array}$ \\
\hline 73 & Fanon, Frantz \\
\hline 61 & Al-Farabi, Abu Nasr \\
\hline 35 & $\begin{array}{l}\text { Lao-tzu (aka Lao Tse, Lao Tze, Lao tzu, Lao Zi, Lao-tse, Laozi, Lao } \\
\text { Tun, Lao Tan, Li Erh) }\end{array}$ \\
\hline 32 & Mao Zedong (aka Mao Tse-Tung) \\
\hline 30 & Qtub, Sayyid \\
\hline 30 & Sunzi (aka Sun-tzu, Sun Wu, Sun Tsu, Sun-tse, Sun Zu) \\
\hline 28 & Ibn Khaldun \\
\hline 26 & Averroës (Ibn Rushd) \\
\hline 23 & Maimonides, Moses \\
\hline 22 & Mencius (aka Mengzi, Meng-tzu, Meng K’o) \\
\hline 18 & Said, Edward \\
\hline 12 & Achebe, Chinua \\
\hline 11 & Mohanty, Chandra Talpade \\
\hline 11 & Spivak, Gayatri \\
\hline 10 & Avicenna (Ibn Sina) \\
\hline 10 & Sen, Amartya \\
\hline 8 & Buddha \\
\hline 8 & Han Fei (aka Han Fei Tse, Han Fei Zi, Han Feizi, Han Fei Tzu) \\
\hline 8 & James, C.L.R. \\
\hline 8 & Nkrumah, Kwame \\
\hline 8 & Shiva, Vandana \\
\hline 7 & Kautilya (author)/Arthashastra (text) \\
\hline 7 & Khomeini, Ruhollah \\
\hline 7 & The Koran \\
\hline 6 & al-Ghazali \\
\hline 6 & Bhabha, Homi \\
\hline 6 & Cesaire, Aimé \\
\hline 6 & Nyerere, Julius \\
\hline 6 & The Bible \\
\hline 5 & Asad, Talal \\
\hline 5 & Bhagavadgita \\
\hline 5 & Zhuangzi (aka Chuang-tzu, Zhuang Zhou) \\
\hline 4 & Biko, Steve \\
\hline 4 & Dostoyevsky, Fyodor \\
\hline 4 & Mariátegui, José Carlos \\
\hline 4 & Memmi, Albert \\
\hline 4 & Nandy, Ashis \\
\hline 4 & Narayan, Uma \\
\hline 4 & Ramadan, Tariq \\
\hline
\end{tabular}


Table 3. Continued

\begin{tabular}{ll}
\hline Votes & \\
\hline 4 & Theorist \\
3 & Aproush, Abdolkarim \\
3 & bin Laden, Osama \\
3 & Cabral, Amílcar \\
3 & Chatterjee, Partha \\
3 & Dussel, Enrique \\
3 & Epic of Gilgamesh \\
3 & Freire, Paulo \\
3 & Ibn Taymiyyah \\
3 & Ibn Tufayl \\
3 & Islamic Political Thought \\
3 & Jesus of Nazareth \\
3 & Las Casas, Bartolomé de \\
3 & Mandela, Nelson \\
3 & Marx, Karl \\
3 & Mernissi, Fatema \\
3 & Nehru, Jawaharlal \\
3 & Ohmae, Kenichi \\
3 & Oyewumi, Oyeronke \\
3 & Parekh, Bhikhu \\
3 & Tagore, Rabindranath \\
\hline
\end{tabular}

Note. Only thinkers who received at least three votes are included in this list.

normative questions, and such courses typically cover a much larger number of ideas and thinkers, but they often give students little or no practice in grappling with the kinds of texts that practicing political theorists themselves read and, in some cases, suffer from breadth-induced superficiality. ${ }^{21}$

The only published data regarding which kinds of texts theorists assign were reported by Hajjar and Brzezinski in 1978. They found that $43.2 \%$ of respondents to their survey of teachers of introductory political theory courses assigned secondary texts, $26.6 \%$ assigned primary texts, and $29 \%$ assigned a combination of the two (Hajjar and Brzezinski 1978, 300). In the present survey, I asked what kinds of texts political theorists use to teach their theory classes-primary texts as monographs, primary texts in anthologies, secondary texts, and other kinds of texts. Table 4 shows the percentages of each type of text that the average respondent uses. Thus, the mean respondent uses about $64 \%$ primary texts as monographs or articles, about $23 \%$ primary texts in an anthology, about $11 \%$ secondary texts, and about $2 \%$ other kinds of texts not mentioned in the question. However, note that the most common (modal) response was that respondents use $100 \%$ primary texts as monographs or articles.

These results suggest that there has been a significant change since 1977 away from using secondary sources like textbooks and towards using primary sources. The most common (modal) teaching practice today is to use only primary texts, and half of the respondents use secondary texts for $2 \%$ or less of the readings they assign, whereas the median percentage of assignments that are primary sources is 
Table 4. Average degree to which respondents use various types of texts

\begin{tabular}{lcccc}
\hline & $\begin{array}{c}\text { Primary texts as } \\
\text { monographs } \\
\text { or articles }\end{array}$ & $\begin{array}{c}\text { Primary texts in } \\
\text { an anthology }\end{array}$ & $\begin{array}{c}\text { Secondary texts } \\
\text { (such as a textbook or } \\
\text { commentary) }\end{array}$ & Other \\
\hline Mean & 64.0 & 22.6 & 11.3 & 2.1 \\
Median & 75.0 & 10.0 & 2.0 & 0.0 \\
Mode & 100.0 & 0.0 & 0.0 & 0.0 \\
\hline
\end{tabular}

$75 \%$. These results suggest that political theory students today may be getting relatively little in the way of a systematic overview of the field, either historical or analytical. While some theorists may think that this is appropriate or even desirable, others may wish to modify their teaching styles to broaden their students' knowledge.

\section{The Point(s) of Political Theory}

In a recent article, Andrew March celebrated what he believes to be a lack of consensus regarding the point of political theory and provided a helpful typology of the loosely related activities that get brought together under that title. He writes:

Of course, the first thing to be observed is that there is no single such thing as political theory. "Political theory" is the name given within the academy to a number of different types of intellectual activities, some of them mutually hostile, which have in common only the fact that they do not aim at empirical explanation or prediction and instead deal with the realms of ideas, concepts, texts, values, and norms.

I think five broad types of activities more or less account for the range of pursuits of those who might be willing to describe their profession as political theory:

1. Normative political philosophy in search of justifiable norms, beliefs, policies, or institutions, whether analytic, critical, or historicaltraditional;

2. Critical analysis and interpretation, which in some way or another aim at exposing the hidden, denied, unrecognized, or unacknowledged underneath the visible, the apparent, or the hegemonic;

3. The history of political thought, including intellectual history, Begriffsgeschichte, and the study of important thinkers;

4. Conceptual analysis at the intersection of philosophy, intellectual history, and social science;

5. The study of forms of political thought and speech at the intersection of discourse analysis, linguistics, social science, psychology, speechact theory, and the study of political ideologies. (March 2009, 533-534)

One of the goals of the survey was to find out what political theorists more broadly think about the issue of the point of political theory. The results both partially support and partially conflict with March's analysis. As you can see from 


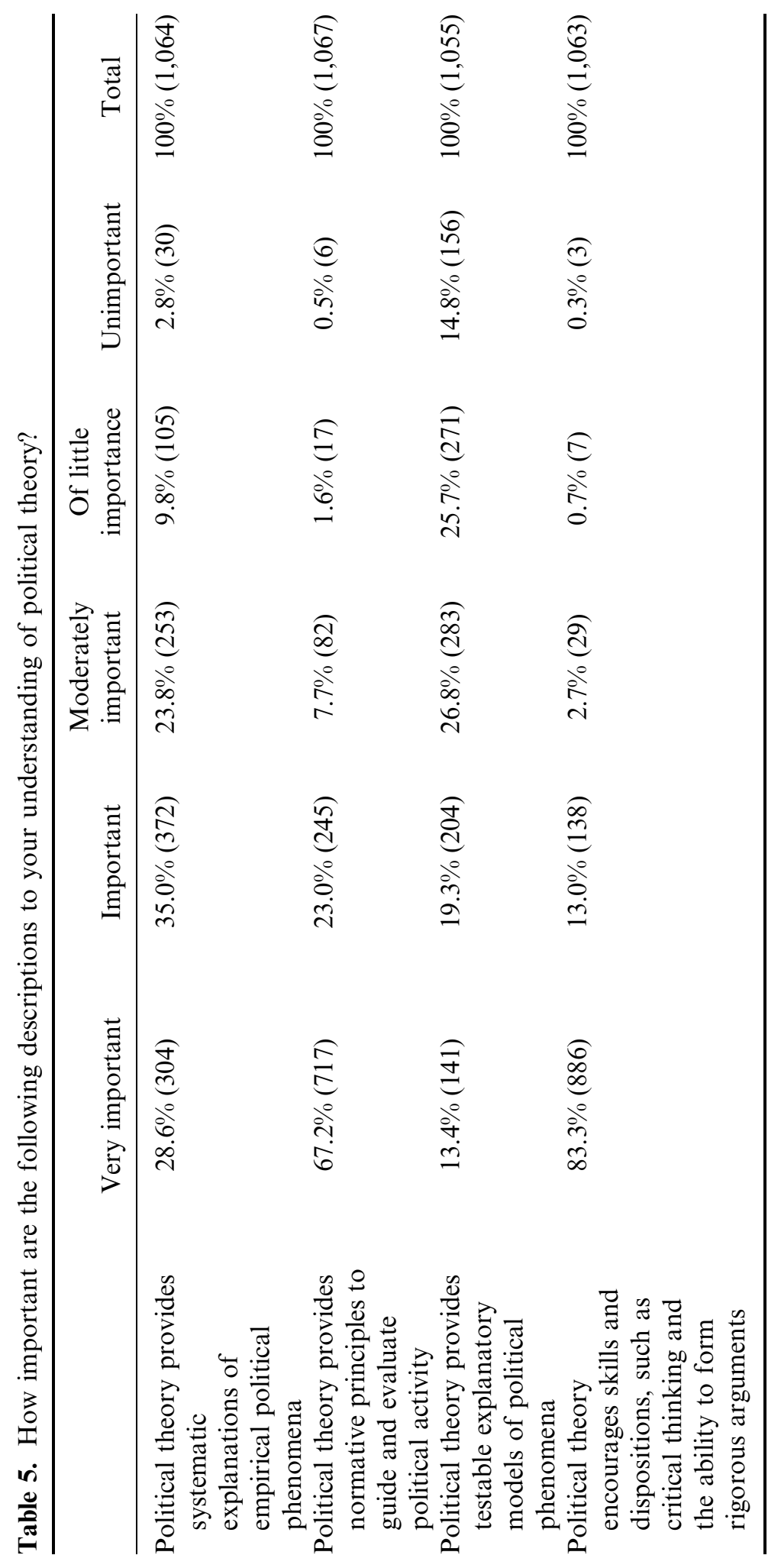


the results, reported in Table 5, my concern was largely to examine respondents' views on two axes - empirical vs. normative, and the imparting of knowledge vs. the development of skills. More than $60 \%$ of respondents thought that providing systematic explanations of political phenomena was either important or very important, though only $33 \%$ felt that it was important or very important for those explanations to take the form of testable models. Fully $90 \%$ of respondents see providing normative principles as being at the heart of political theory, and $96 \%$ see encouraging particular skills and dispositions as being either important or very important. These results suggest that the traditional normative/empirical split between political theory and other parts of political science is real but probably exaggerated. They also suggest that the significant majority of political theorists are motivated by the desire to develop and/or assess normative principles for politics. These results suggest that the first two of March's categories make up the majority of the interests of political theorists.

However, a number of respondents wrote me to say that they thought my conceptualization of theory was too narrow, and that their own views were not well represented by any of the available answer choices. This suggests that a broader question, perhaps informed by March's categories (which had not been published at the time the survey was conducted) might show that the concerns and motivations of theorists are in fact broader than they appear to be in Table 5 . While it is obviously too late to ask the questions differently, this feedback indicates that the issue of the point of political theory remains in dispute, both among theorists and between theorists and other political scientists. (I am distinguishing the question of the point of theory from the question of the role of theory within political science, which I discuss elsewhere. $)^{22}$

\section{The Point of Teaching Political Theory}

A related but distinct question concerns what the point of teaching political theory is. Aside from training new generations of academic political theorists, what is the point of teaching political theory, especially to undergraduates? What do we expect students to gain from studying theory? One helpful place to begin is to ask what the point of political science is, in particular the point of political science education. Although a great deal of work has been done on this topic, the Wahlke Report of 1991 remains the authoritative discussion of this question. ${ }^{23}$ Written as part of the Association of American Colleges' (AAC) national review of arts and sciences majors, the report summarized the work of the Task Force on the Political Science Major. The report's main conclusion about the goals of political science education was as follows:

The first premise of our report is the belief that the goal of liberal education is the development of students' general intellectual abilities - curiosity, powers of critical analysis, aesthetic appreciation, and creativitythus equipping them "to master complexity," "to undertake independent work, and [to attain] critical sophistication." We think disciplinary major programs should also consciously seek to foster the nine "elements" (also termed "experiences" and "criteria or objectives" of such education) described in the AAC Report: (1) Inquiry: abstract logical thinking, critical analysis; (2) Literacy: writing, reading, speaking, listening; (3) Understanding numerical data; (4) Historical consciousness; (5) Science; (6) Values; (7) Art; (8) International and multi-cultural experiences; (9) Study in depth. (Wahlke 1991, 48-49; internal citations omitted) 
Narrowing the topic to the question of the point of teaching theory, Joel Kassiola's 2007 article "Effective Teaching and Learning in Introductory Political Theory" lays out a clear set of goals. He argues:

The first goal is to familiarize students with the 2,400-year-old, grand tradition of Western political theory beginning with Socrates/Plato and extending to the present. Second, instructors usually seek to provide students with a conceptual framework for the academic field that includes the questions and issues political theorists have focused upon throughout the ages, such as political obligation, the right of revolution, and equality (just to name a few). A third goal is to teach students how to read and comprehend challenging theoretical texts and to write rationally persuasive essays defending their own judgments of political value and political prescriptions in reaction to the readings and class discussion. A final main objective is to improve students' critical thinking skills. (Kassiola 2007, 783)

The survey asked respondents to rank these and other goals of teaching political theory. The results are summarized in Table 6.

Because respondents were asked to rank the relative importance of the various purposes of teaching theory, we can discriminate among Kassiola's three main goals. Thus, just under half of respondents see leading students to mastery of a body of knowledge/writing as being very important, but nearly two-thirds see a major goal of teaching theory as contributing to a well-rounded education, nearly $70 \%$ see teaching skills such as critical thinking and expository writing as being a very important goal, and a slightly larger number see enabling criticism of accepted ideas and institutions as being very important. These results suggest that Kassiola's three main goals are important to theorists; though some other goals are equally or more important. Likewise, they suggest that political theorists emphasize some elements of the Wahlke Report more than others, especially Inquiry, Literacy, and Values.

The survey results also reveal the positions that theorists generally have taken on various debates within the discipline. For example, over the past 20 years there has been an enormous amount of debate about the role of "civic education" in political science, and political theorists such as Jean Elshtain have played a prominent role in those discussions (see Carter and Elshtain 1997). Yet, 22.9\% of respondents identified "encouraging political participation" as being of little importance or unimportant, and only $16.5 \%$ identified it as being very important. The $60.7 \%$ who identified it as important or moderately important clearly show that theorists do think political participation is one goal, but it is not among their main goals. Similarly, the question of professors' partisanship or advocacy in the classroom is a perennial source of concern and debate, both within the profession and between professors and students. For example, see the recent work by Matthew Woessner and April Kelly-Woessner (Kelly-Woessner and Woessner 2006; Woessner and Kelly-Woessner 2009). Respondents to the survey largely disavowed any intention of encouraging students to adopt particular views, with $70.7 \%$ saying that "imparting particular views or beliefs" is either of little importance or unimportant, and with only $10.7 \%$ saying that that goal was either very important or important. However, respondents overwhelmingly endorsed the goal of "enabling criticism of accepted ideas and institutions," with $93.6 \%$ identifying that as either very important or important. To the extent that 


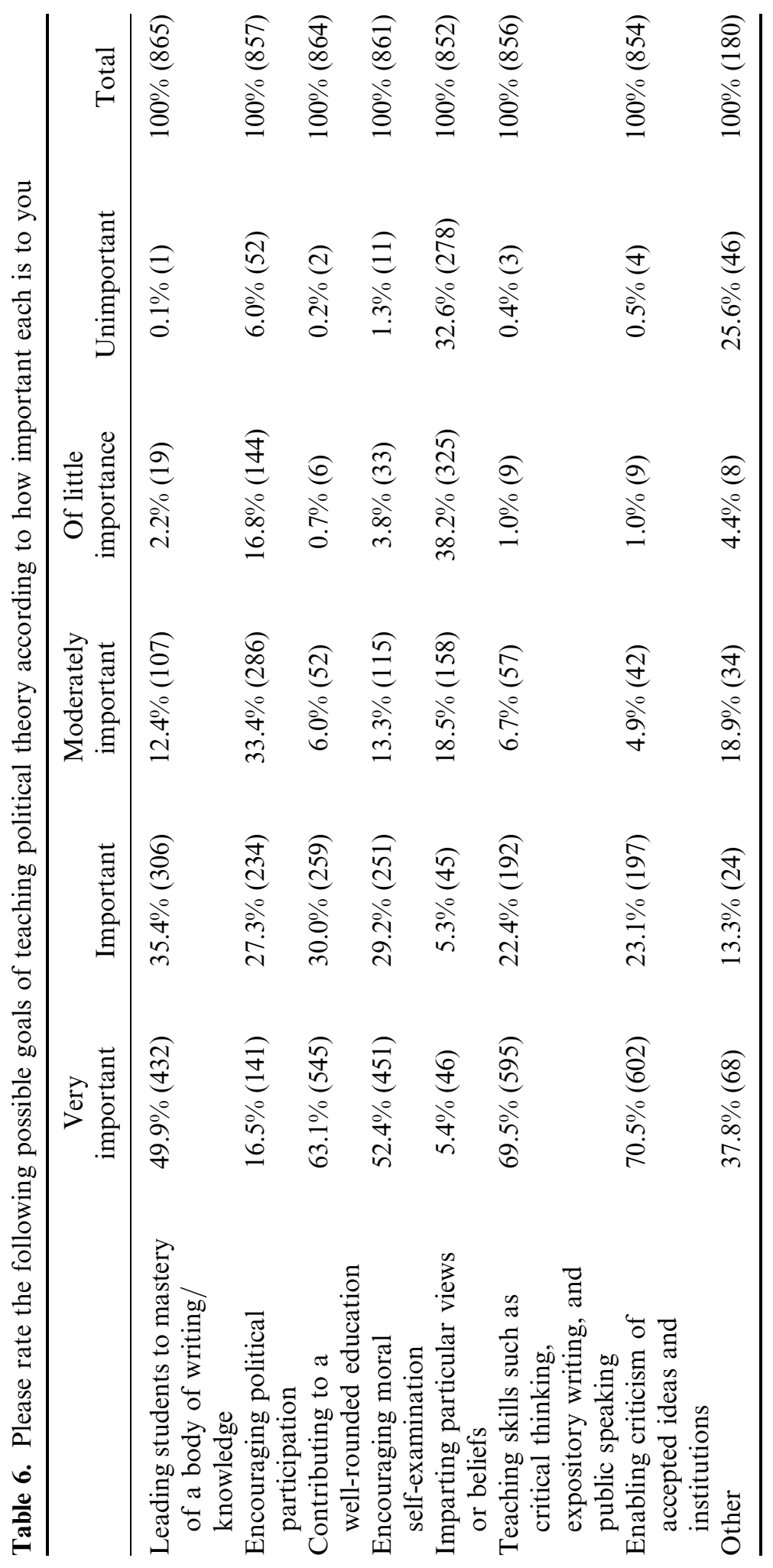


criticizing accepted ideas and institutions implies or requires making particular value judgments, this goal may conflict with respondents' disavowal of encouraging students to adopt particular views or beliefs.

\section{How Theorists Teach}

Over the past 20 years there has been an explosion of research and publication on teaching and learning, both within political science (hence the creation of a special section of PS: Political Science and Politics on "The Teacher" in 2002, the initiation of the APSA's annual Teaching \& Learning Conference in 2004, and the launching of the Journal of Political Science Education in 2005), ${ }^{24}$ and in the academy more broadly. ${ }^{25}$ Many of these studies have focused either on explaining an innovative teaching methodology or on testing some such method, usually through a single case study or small- $N$ survey. Thus, while we have learned a great deal about how our teaching might become more effective, we know relatively little about whether individual professors or departments are actually implementing the various proposed innovations. One goal of the survey was to investigate the degree to which political theorists have adopted a variety of pedagogical methods, both in the classroom (for example, simulations or dramatic enactments) and outside (for example, course Web sites). While it is unknown to what degree the teaching of theorists is representative of the teaching of other political scientists, I believe that these data should be of interest to the profession more broadly, since they offer some initial information about how we teach today.

\section{Teaching Methods Theorists Use in the Classroom}

A first set of questions asked respondents to indicate how frequently they use various teaching methods in their political theory classes. The results are summarized in Table 7.

What do we learn from these results? Before conducting the survey, I had hypothesized that political theorists would be likely to use "traditional" methods such as lecture and discussion, and relatively unlikely to adopt "newer" methods like the use of films, service-learning, and so on. This hypothesis rested partially on the nature of political theory texts - they are often difficult to understand and require both careful reading and extensive in-class discussion or explanation. Thus the subject matter lends itself readily either to lecture or to a semi-Socratic approach to teaching. The hypothesis also rested upon a hunch that political theorists tend to overemphasize the uniqueness of their field, and that they resist using novel techniques that would in fact be both practical and effective. The results strongly confirm the prediction that political theorists use almost exclusively lecture and discussion, and that they use other methods less often (and in some cases hardly at all). Unfortunately, there was no manageable way to tell whether this is due to the nature of theoretical texts or due to theorists' stubbornness, so the resolution of that question will have to wait for further research.

Secondly, here, too, the responses reveal a great deal about how theorists have responded to recent debates within the discipline. The responses show that, despite the prominence of political theorists such as Benjamin Baber in the discussion of service-learning in political science education (see Barber and Battistoni 1993), respondents report using service-learning in their courses almost not at all. 


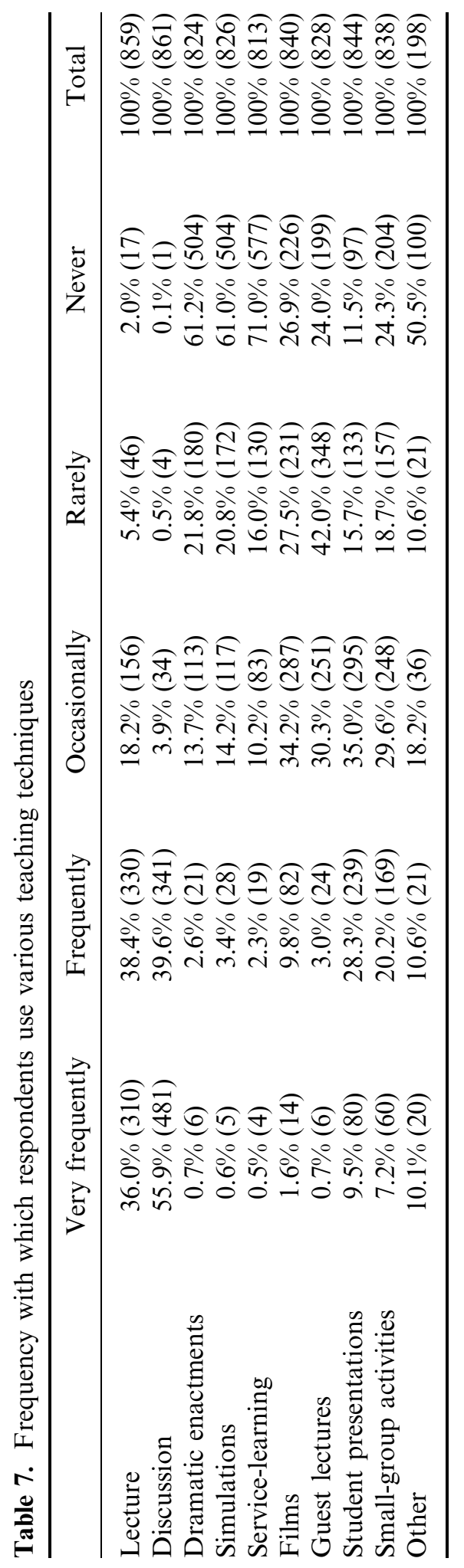


Simulations and dramatic enactments are also apparently rarely used (on simulations see Asal and Blake 2006). However, nearly 39\% of respondents report at least occasionally using teaching techniques not listed in my question, which suggests that some of the innovative techniques reported in recent literature - such as Freie's (1997) dramaturgical method, Miller's (2000) method of connecting political theory with the visual arts, and Mott's (2008) use of the personal essay in political theory classes - may in fact be getting used more than these results indicate.

\section{Online Teaching}

In addition to the techniques being used in the classroom, I was interested in what pedagogical techniques political theorists were using outside of the classroom, particularly online. I distinguished between hybrid classes (those with both face-to-face and online components) and classes taught entirely online (aka distance learning). There is already a substantial literature on online teaching in political science, including reports of quasi-experiments in online teaching (Botsch and Botsch 2001; Dolan 2008; Garson 1998; Pollock and Wilson 2002; Wilson et al. 2006), as well as case studies of the use of particular techniques, such as podcasting (Roberts 2008; Taylor 2009), blogging (Lawrence and Dion 2010), online discussions (Clawson et al. 2002), and teaching electronic information literacy (Dolowitz 2007), along with expressions of concern about the impact of the Internet on student learning (Barberio 2004; Robinson and Schlegl 2005). Reviewing both the existing literature and her own experimental data, Kathleen Dolan concludes that both hybrid classes and fully online courses can be as effective as traditional courses (Dolan 2008, 387). Indeed, there is some evidence that students in hybrid and online courses do better than students in traditional courses (see Botsch and Botsch 2001; Pollock and Wilson 2002). However, as Dolan notes, we are still in the process of evaluating how well online teaching works, and there are open questions about whether it works better for some subjects or course levels (Dolan 2008, 390-391).

Given both the existing research suggesting that online teaching is effective and the open questions about whether online teaching is appropriate for all subjects, I was curious to find out to what degree political theorists had actually done any online teaching, and what their experiences of it had been. I had hypothesized that political theorists would be relatively unlikely to embrace teaching completely online courses, on the grounds that political theory texts require a kind of intensive explication that would be difficult or time consuming to deliver online (or, as above, because political theorists believe that about the texts they teach). However, there seems to be no discipline-specific reason for political theorists to avoid other technologies, such as online quizzing or submission of papers, and so I hypothesized that they would be relatively likely to have adopted them.

The survey results confirmed my first hypothesis that political theorists were unlikely to have adopted completely online teaching. Of the 871 respondents who answered this question, $96.2 \%$ (838) said that they have not taught a political theory class entirely online, while only 3.8\% (33) said that they had. Among those who reported having taught a theory class or classes entirely online, 34.4\% (11) said the class(es) had been successful, 15.6\% (5) said the class(es) had been unsuccessful, and 50\% (16) reported mixed experiences with online teaching. Those who reported not having taught a theory class entirely online were asked whether they would like 
to do so in the future: $75.6 \%$ (631) said "no," 5.7\% (48) said "yes," and 18.7\% (156) reported that they were not sure.

The results regarding theorists' use of other online technologies surprised me and appear to disconfirm my hypothesis that political theorists were likely to adopt such technologies. The survey asked whether the respondent uses online teaching methods beyond posting syllabi and readings, which appear to have now become standard practices. A total of 858 respondents answered this question: 73\% (626) said that they do not use online teaching methods, while $27 \%$ (232) said that they do. On their face, these data suggest that only a minority of theorists have adopted using online technologies. Absent comparison data for the profession, it's not possible to know how this compares to the rates of usage by other subfields or the discipline as a whole. It's possible that there may be a generational effect; since older people are less likely to adopt new technologies than younger people, and since political theorists are on average older than political scientists generally, we have reason to suspect that theorists may be less likely to adopt new technologies. It will be interesting to see if further research confirms this possible explanation.

Those who reported using some online technologies were then asked a follow-up question about which particular methods they use. Their responses are summarized in Table 8.

These results suggest that the theorists who are using online techniques are largely using them to duplicate pedagogical and administrative tasks from the face-to-face world, rather than using them to do things that are unique to the online world. For example, the most commonly used online tool is online submission of assignments, and the second most commonly used tool is an online blackboard/ whiteboard; both tools replicate and facilitate physical-world tasks. Truly online techniques, like creating a wiki (a collaborative text, for example a study guide) were used rarely. Overall, it seems that theorists have adopted online techniques slowly, and mostly to replace existing tasks and techniques.

Table 8. Online teaching methods used by respondents who report using any such methods

\begin{tabular}{|c|c|c|}
\hline & $\begin{array}{c}\% \text { who report } \\
\text { using this technique }\end{array}$ & $n$ \\
\hline Online chat & 45.3 & 102 \\
\hline Online blackboard/whiteboard & 62.7 & 141 \\
\hline Class wiki/collaborative study guide & 14.7 & 33 \\
\hline Posting model assignments & 36.9 & 83 \\
\hline Online simulations or role-playing activities & 6.7 & 15 \\
\hline Online posting of grades & 47.6 & 107 \\
\hline Online quizzing or testing & 22.2 & 50 \\
\hline Online submission of assignments (digital dropbox) & 63.1 & 142 \\
\hline Online grading/markup of assignments & 36.9 & 83 \\
\hline Other & 25.8 & 58 \\
\hline
\end{tabular}

Note. Respondents could indicate that they use more than one technique. $N=225$. 
Finally, in a related question, 62.5\% (541) respondents said they had not used PowerPoint or other presentation software in their theory classes, while $37.5 \%$ (324) said that they had used such software. This result suggests that theorists overall have been slow to adopt new technology.

\section{Assessment}

Over the past 20 years, the issue of assessing the effectiveness of both teaching and learning in political science has gone from the margins to the center of the discipline. In 1991, the Wahlke Report could conclude: "Evaluation of students' over-all performance is probably the most neglected element of the major program. It often amounts to little more than a summation of discrete performances in the courses taken. Ideally, students' learning and performances should be measured not only in course examinations and a final round of 'comprehensive exams,' but at regular intervals, against norms or bench-marks based on expectations of where they ought to be at different stages in their undergraduate career. Unfortunately, we know of no such current practice, and strongly suspect that the faculty time and energy needed to devise and implement such a plan would tax the resources of many departments beyond their capacity" (Wahlke 1991, 55). In that same year, Julian et al. (1991) surveyed the state of assessment in political science departments and concluded that while some departments had begun formal assessment efforts, many either had not done so or had not even considered the question. They wrote: "While it is understandable that a professor may care little for the idea of measuring outcomes, it is much more difficult to understand how political scientists could be ignorant of such a massive educational and political movement" (Julian et al. 1991, 208). Thirteen years later, the title of Smoller's article (2004) both acknowledged and challenged the fact that resistance to assessment was still common: "Assessment Is Not a Four-Letter Word." The recent publication of Deardorff, Hamann, and Ishiyama's Assessment in Political Science by the APSA (2009) neatly symbolizes the change that has taken place since then. Building on a substantial body of research about assessment within political science, ${ }^{26}$ the book is based on the assumption that all political science departments will be engaged in assessment and then offers practical advice about how to do it well.

I was interested to investigate several questions regarding assessment in the survey. First, I wanted to know how broadly assessment had been implemented in political science, following up on the earlier survey work by Ishiyama and Breuning (2008) and Kelly and Klunk (2003). To that end, I asked respondents whether their department or school required explicit assessment statements and/or procedures. Of the 869 respondents who answered this question, $72.3 \%$ (628) said "yes," $21.5 \%$ (187) said "no," and 6.2\% (54) reported not being sure. Although it's not possible to determine whether this is representative of political science as a whole, it at least suggests that assessment is now widespread, probably more widespread than seven years ago, when Kelly and Klunk found that roughly $50 \%$ of departments were engaged in assessment $(2003,451)$.

A second question addressed whether the respondents were complying with their department or school's assessment requirements. I had hypothesized that political theorists might be especially prone to resisting assessment, on the grounds, that political theory learning is difficult to measure. To put it crudely, it's relatively easy to test whether a student can perform a regression, but at least apparently harder to 
Table 9. Political theory's suitability for explicit assessment

\begin{tabular}{|c|c|c|}
\hline & $\%$ & $n$ \\
\hline $\begin{array}{l}\text { Political theory is especially well suited to } \\
\text { explicit assessment. }\end{array}$ & 5.7 & 35 \\
\hline $\begin{array}{l}\text { Political theory is neither better nor worse } \\
\text { suited to explicit assessment than other } \\
\text { subfields in political science. }\end{array}$ & 65.2 & 404 \\
\hline $\begin{array}{l}\text { Political theory is especially ill-suited to explicit } \\
\text { assessment. }\end{array}$ & 18.5 & 115 \\
\hline No opinion/Not sure & 10.6 & 66 \\
\hline Total & 100 & 620 \\
\hline
\end{tabular}

test whether the experience of reading Rousseau has led them to reflect on their prior political beliefs. However, this hypothesis was not borne out by the data. Of the 620 respondents who answered the question, 91.1\% (565) reported that they had followed their institution's requests or requirements regarding assessment, while $8.9 \%$ (55) reported that they had not. Even without comparison data for other subfields within political science, it is obvious that political theorists have not resisted explicit assessment to any great degree, and it seems unlikely that the $8.9 \%$ noncompliance rate could be significantly larger than that of other subfields. (Indeed, these numbers raise the tantalizing but currently unanswerable question of whether theorists have in fact embraced explicit assessment more eagerly than other political scientists.)

Just to double-check that result, I also asked respondents about a third issue: whether in their view political theory was better or worse suited to assessment than other subfields in political science. Again, my initial hunch that theorists would see theory as especially badly suited to assessment was not borne out. The results summarized in Table 9 clearly show that the significant majority of respondents see no difference between theory and other subfields when it comes to suitability for explicit assessment.

A fourth and final question regarding assessment had to do with whether it is of any value. There is some case-study-based evidence that assessment improves student learning in political science, ${ }^{27}$ and also some more systematic evidence. ${ }^{28}$ Yet, only $27.4 \%$ of respondents (169) thought that assessment definitely improved learning, while $33.3 \%$ (206) thought that it did not, and 39.3\% (243) weren't sure. This suggests either that political theorists are not aware of the research regarding the effectiveness of assessment, or that they are skeptical about its apparent findings. Regardless of which reason is behind these results, it is clear that many political theorists (and perhaps many political scientists more broadly) are not convinced that assessment improves learning. It seems unlikely that assessment will be embraced as anything other than a bureaucratic chore until that skepticism is overcome.

\section{Differentiated Instruction}

Differentiated instruction is the practice of tailoring teaching to individual students, based on their varying learning styles, levels of background knowledge, and degrees of interest. Primary and secondary education long ago adopted differentiated 
instruction, and there has been some discussion of it in the political science literature, such as work on student learning styles (Brock and Cameron 1999; Driver et al. 2008; Fox and Ronkowski 1997). The most comprehensive research within political science so far has been Ernst and Ernst's 2005 article both reviewing previous research and reporting the successful results of a case study. Ernst and Ernst report that students in a class that employed differentiated instruction generally supported that approach, and that the faculty member reported an overall positive experience as well; though the professor did express concerns about whether differentiated instruction is fair (Ernst and Ernst 2005, 56).

The survey sought to investigate these questions by asking whether respondents were aware of differentiated instruction, whether they practice it, whether they believe it is effective, and how they evaluate its fairness. Of respondents who answered a question that provided a brief description of differentiated instruction and then asked whether they offered differentiated instruction in their political theory classes, $74.3 \%$ (633) said that they do not, while $22.3 \%$ (190) said that they do, and $3.4 \%$ (29) weren't sure. Similarly, of respondents who answered a question asking whether students offered differentiated instruction learn more than students not offered differentiated instruction, 12.2\% (104) said "yes," 21.6\% (184) said "no," while the vast majority of $66.2 \%$ (564) weren't sure. Likewise, when asked whether differentiated instruction is fair to students, $29.4 \%$ (249) said "yes," 20.2\% (171) said "no," and $50.4 \%$ (427) weren't sure. These results suggest that political theorists largely do not practice differentiated instruction, that they are not sure whether it is effective, and that they are likewise unsure about whether it is fair. Overall, differentiated instruction seems to have made little headway among theorists.

\section{How Do Schools Handle Political Theory?}

A final series of questions asked about how the respondent's home institution handles political theory. A first question asked about the number of students in undergraduate, introductory political theory classes; the results are summarized in Table 10.

The significance of the findings reported in Table 10 is probably a matter of taste. Given the constant pressure to increase class sizes on the one hand, and the difficulty of engaging large groups of students in close reading and explication on the other, the fact that more than $80 \%$ of introductory theory classes have 50 or

Table 10. Number of students in an introductory-level, undergraduate political theory class

\begin{tabular}{lrr}
\hline & $\%$ & $n$ \\
\hline $0-10$ & 4.3 & 33 \\
$11-25$ & 38.3 & 293 \\
$26-50$ & 39.1 & 299 \\
$51-75$ & 5.4 & 41 \\
$76-100$ & 5.0 & 38 \\
more than 100 & 7.9 & 60 \\
Total & 100 & 764 \\
\hline
\end{tabular}


fewer students strikes me as good news overall. However, I can imagine other theorists drawing that compromise line elsewhere.

A second question asked how many different political theory classes appear in the respondent's department's course catalog. Based on 739 responses, the mean number of courses was 7.25, while the median was 6.00 and the mode was 5. Given that the survey found that $26 \%$ of schools that teach at least some political science classes do not offer any classes in political theory (in the same department), it strikes me as encouraging that the average school that does teach theory teaches so much of it. It would be relatively easy to consign theory to a single introductory course, and the fact that many departments offer much more than that is good news for theory. (On the other hand, the fact that more than a quarter of schools that teach political science don't teach any theory is plainly bad news.)

Respondents whose departments offer more than one theory class were asked how those classes divide up the material. Of 759 responses, $15.6 \%$ (118) said that their department divides political theory into separate classes historically, $10.1 \%$ (77) said that they divide the material thematically, and an overwhelming majority of $74.3 \%$ (564) said that they divide the material both historically and thematically. These results conflict with Jeffrey Johnson's (2008) argument that theory classes tend to be organized historically, and that that structure tends to treat theory as intellectual history rather than as a source of normative guidance and challenges. Instead, the survey suggests many and perhaps most departments approach theory both historically and thematically, thus treating theory both as intellectual history and as an aid to moral reflection on particular themes or issues.

Of respondents who answered a question asking whether their department offers an undergraduate major in political science, 93.9\% (728) said "yes," while $6.1 \%$ (47) said "no." The responses regarding the number of majors included some that seem implausibly high $(3,000$ and 5,000$)$, so I think we should treat the calculated mean of 244 with skepticism. However, the median of 110 seems plausible. Of those respondents teaching in departments with undergraduate majors, 76.7\% (549) report that their department requires undergraduate majors to take at least one theory class, while $23.3 \%$ (167) report that their department does not require any theory courses. This last finding suggests that the question of the role of political theory within political science remains under debate, and that theory's uncertain position within the discipline is played out at the level of the undergraduate curriculum.

Finally, respondents were asked whether their undergraduate majors were required to complete a concentration within the major, and if so whether that concentration could be in political theory. Of 712 respondents who answered this question, just under half $(46.2 \%$ or 329$)$ reported that their department does not require a concentration for majors, $14.8 \%$ (105) reported that majors could not concentrate in political theory, $32.4 \%$ (231) reported that majors could concentrate in theory, and $6.6 \%$ (47) reported that majors could only concentrate in theory as part of an independent or self-designed concentration. Interestingly, this finding seems to reinforce the previous result regarding theory in the major. Among respondents whose departments require a concentration within the major, $73 \%$ reported that their department allows that concentration to be in theory (either directly or through a self-designed program), while $27 \%$ reported that their department does not allow a concentration in theory under any circumstances. This again suggests that the place of theory within political science remains unsettled. 
Table 11. Undergraduate political theory programs in rank order

\begin{tabular}{|c|c|}
\hline Weighted votes & School name \\
\hline 541 & NJ - Princeton University \\
\hline 511 & MA - Harvard University \\
\hline 431 & IL - University of Chicago \\
\hline 258 & CT - Yale University \\
\hline 188 & MA - Amherst College \\
\hline 180 & IN - University of Notre Dame \\
\hline 176 & CA - University of California: Berkeley \\
\hline 162 & MA - Williams College \\
\hline 150 & NC - Duke University \\
\hline 150 & $\mathrm{OH}$ - Kenyon College \\
\hline 140 & MA - Boston College \\
\hline 118 & NY - Columbia University \\
\hline 115 & PA - Swarthmore College \\
\hline 110 & DC - Georgetown University \\
\hline 99 & MD - Johns Hopkins University \\
\hline 83 & IL - Northwestern University \\
\hline 82 & $\mathrm{CA}$ - Pomona College \\
\hline 77 & RI - Brown University \\
\hline 76 & CA - Claremont College / Graduate University \\
\hline 75 & $\mathrm{OH}$ - Oberlin College \\
\hline 72 & CA - University of California: Los Angeles \\
\hline 71 & MI - University of Michigan \\
\hline 68 & CA - Stanford University \\
\hline 59 & MN - Carleton College \\
\hline 58 & WA - Whitman College \\
\hline 53 & OR - Reed College \\
\hline 51 & TX - University of Texas at Austin \\
\hline 51 & MD - St. John’s College \\
\hline 50 & CA - University of California: Santa Cruz \\
\hline 49 & NY - Cornell University \\
\hline 44 & MI - Hillsdale College \\
\hline 40 & TX - Baylor University \\
\hline 38 & TX - University of Dallas \\
\hline 38 & University of Toronto \\
\hline 35 & CT - Wesleyan University \\
\hline 34 & $\begin{array}{l}\text { NJ - Rutgers, The State University of NJ: New } \\
\text { Brunswick Regional Campus }\end{array}$ \\
\hline 34 & VA - University of Virginia \\
\hline 34 & DC - Catholic University of America \\
\hline 33 & MA - Smith College \\
\hline 27 & NY - New York University \\
\hline 27 & TN - Rhodes College \\
\hline 27 & ME - Bowdoin College \\
\hline
\end{tabular}


Table 11. Continued

\begin{tabular}{|c|c|}
\hline Weighted votes & School name \\
\hline 26 & CA - University of California: San Diego \\
\hline 24 & MI - Michigan State University \\
\hline 24 & MN - University of Minnesota: Twin Cities \\
\hline 24 & Oxford University \\
\hline 24 & PA - University of Pennsylvania \\
\hline 24 & NY - New School University \\
\hline 22 & $\begin{array}{l}\text { LA - Louisiana State University and Agricultural and } \\
\text { Mechanical Sciences }\end{array}$ \\
\hline 21 & MA - Tufts University \\
\hline 20 & $\mathrm{CO}$ - Colorado College \\
\hline 19 & MA - University of Massachusetts Amherst \\
\hline 19 & NC - Davidson College \\
\hline 19 & GA - Emory University \\
\hline 18 & NC - University of North Carolina at Chapel Hill \\
\hline 18 & WA - Evergreen State College \\
\hline 18 & WI - University of Wisconsin-Madison \\
\hline 18 & MA - Mount Holyoke College \\
\hline 17 & NH - Dartmouth College \\
\hline 16 & MO - Washington University in St. Louis \\
\hline 15 & GA - Berry College \\
\hline 14 & HI - University of Hawaii at Manoa \\
\hline 13 & IL - Northern Illinois University \\
\hline 13 & NY - Hobart and William Smith Colleges \\
\hline 13 & MA - College Of The Holy Cross \\
\hline 12 & MA - Wellesley College \\
\hline 12 & NY - Fordham University \\
\hline 12 & NY - Hamilton College \\
\hline 12 & NY - Bard College \\
\hline 11 & OR - Willamette University \\
\hline 11 & PA - Haverford College \\
\hline 11 & VA - Hampden-Sydney College \\
\hline 11 & York University (Canada) \\
\hline 11 & WA - University of Washington \\
\hline 10 & Cambridge University \\
\hline 9 & IL - Loyola University of Chicago \\
\hline 9 & NY - City University of NY: Brooklyn College \\
\hline 9 & NY - Syracuse University \\
\hline 9 & NY - Vassar College \\
\hline 9 & $\mathrm{OH}$ - Ashland University \\
\hline 9 & RI - Providence College \\
\hline 9 & $\mathrm{TN}$ - Vanderbilt University \\
\hline 9 & VA - Washington and Lee University \\
\hline 9 & GA - Morehouse College \\
\hline
\end{tabular}


Table 11. Continued

\begin{tabular}{ll}
\hline Weighted votes & \multicolumn{1}{c}{ School name } \\
\hline 8 & NY - Eugene Lang College The New School for Liberal \\
& Arts \\
8 & CA - San Francisco State University \\
7 & CA - University of Southern California \\
7 & FL - Palm Beach Atlantic University \\
7 & IA - Grinnell College \\
7 & PA - Villanova University \\
7 & TX - Texas A \& M University \\
7 & VA - Virginia Polytechnic Institute and State University \\
7 & CO - University Of Colorado At Boulder \\
6 & IN - Indiana University Bloomington \\
6 & NY - Sarah Lawrence College \\
6 & VT - Marlboro College \\
6 & CA - Loyola Marymount University \\
\hline
\end{tabular}

Note. Respondents were asked to list up to five schools in rank order. To calculate the weighted totals, a first-place vote was given five points, a second-place vote was given four points, and so on. Only schools that received a weighted score of 6 or higher are included; this ensures that all the schools listed received at least two votes.

\section{What Undergraduate Departments Are Doing a Great Job Teaching Theory?}

Last but not least, I asked what five undergraduate departments the respondents would recommend to a promising high school student interested in studying theory. The problems with this kind of opinion-based ranking are well known, but, as is often the case, imperfect data are better than none, and prior to the survey we have had no information about what undergraduate programs are doing a good job in theory. Table 11 shows the schools in rank order.

\section{Conclusion}

Taken as a whole, what do the results of the survey tell us about the current state of political theory, and by implication of political science more broadly? I suggest that there are four main lessons. First, it appears that political theory as taught is more diverse than we might have predicted. When asked what thinkers should be taught more or taught less, respondents named 704 thinkers (only 152 of whom appear in Table 2). This is far more than the usual suspects of the Western canon. Further, as I indicate above, there appears to be substantial disagreement among theorists about the value of teaching a number of thinkers, from Judith Butler to John Locke. While some may see these findings as indications of curricular incoherence, I see them as evidence of a healthy pluralism. No one text or thinker is the single best option for getting students to engage with the questions of authority, or identity, or the nature of political obligation, and the actual practice of political theorists in the classroom reflects that fact. 
Second, the long-debated question of the role of political theory within political science continues to be an issue. As noted above, $26 \%$ of schools that teach any political science teach no political theory. Of respondents who teach at schools that do teach theory and have a political science major, 23\% report that the major does not require students to take any political theory classes. Further, of respondents whose department's major requires a concentration, $27 \%$ report that the concentration cannot be in political theory. Because the unit of analysis was the individual teacher and not the department, there is no way to definitely convert these last two data points into measures about how many departments have adopted these policies. However, since relatively few departments had more than one or two respondents, we can gain a rough estimate of how theory is treated at the department level from these findings. Based on the survey, it is clear that political theory is treated as being not essential to political science in a disturbingly large proportion of political science departments.

Third, it is clear that political theorists have generally not adopted many of the innovations in teaching that the literature on teaching and learning has both investigated and celebrated over the past 20 years. As explained above, political theorists have largely not embraced civic education, service-learning, simulations, dramatic enactments, the use of film in the classroom, blogging, the creation of wikis, distance education, differentiated instruction, or the use of presentation software. As I have suggested briefly above, there are three possible explanations for these "failures" to embrace new pedagogies: ignorance, stubbornness, and skepticism. It may be that political theorists are simply ignorant of these methods and technologies and have not considered adopting them. Alternately, it may be that, despite being aware of these pedagogical techniques, and perhaps even being aware of the existing though limited research on their effectiveness, political theorists are simply stubbornly refusing to adopt them. Finally, it may be that political theorists are simply not persuaded by the existing scholarship that the methods and techniques are genuinely useful, perhaps due to the relatively modest scope of most evaluation studies. Whatever the reason is, the clear message is that political theorists as a group are largely not embracing the ostensible innovations in pedagogy that the discipline has been discussing for the past 20 years. Given that finding, it would be very interesting to know whether political theorists are outliers or bellwethers - in other words, have political scientists generally adopted these new approaches in any greater numbers, or are political theorists representative of the discipline as a whole? My survey cannot answer this question, but it seems clear that it would be very helpful to the scholarship of teaching and learning to learn the answer through additional research.

Fourth and along the same lines, the survey makes clear that while most political theorists are in fact engaged in assessment of student learning, they are largely either skeptical or agnostic about whether assessment is of any value in improving learning. One reason for that may be that the evidence of the effectiveness of assessment, at least within the political science literature, is quite thin. The vast majority of the literature reports small-scale case studies or, more often, explains how a particular department conducts assessment. There is very little systematic evidence that assessment improves learning in political science, even in the state-of-the-discipline volume edited by Deardorff, Hamann, and Ishiyama (2009). Thus, again, theorists' uncertainty about assessment may be rooted in ignorance, stubbornness, or skepticism, but one way or the other, theorists have not yet been convinced of the value of assessment. To the extent that the respondents to the survey are representative of the profession more broadly, it may be the case that political scientists generally have not yet been convinced that assessment improves learning. 
Overall, the survey suggests that there is a great deal of work to do. First, for those of us who believe that political theory is an essential part of political science, there are several hundred political science programs that need encouragement to change their curricula to more centrally incorporate theory or even teach it at all. Second, for those interested in pedagogical and technological innovation in teaching, there is still a lot of work to do both publicizing existing scholarship and demonstrating to the discipline the value of these innovations. Third, for all of us involved in assessment (and that does appear to be virtually all of us), there is a pressing need to determine whether assessment helps students learn more and to publicize our findings. Finally, there is not a need but an opportunity to use the results of the survey to reflect on the vitality of political theory as a subfield, to learn from what and how our colleagues are teaching, and to aspire to become both better political theorists and better political scientists.

\section{Notes}

1. An earlier version of this paper was presented at the 2009 American Political Science Association Teaching \& Learning Conference in Baltimore, Maryland. I am grateful to other participants in my track, many of whose suggestions have been incorporated in this revision. I would also like to thank Prof. Jeff Sklar of the Statistics Department of Cal Poly State University, San Luis Obispo, for his generous assistance as part of the university's Statistical Consulting Service.

2. The results regarding theory's place in the profession have been published as: Moore, M. J. (2010). "Political Theory Today: Results of a National Survey." Ibid. 43(2): 265-272.

3. For a concise overview, see Gunnell (2006).

4. To my knowledge, the only other recent survey of political theorists was conducted in 1977 and received 172 usable answers. See Hajjar and Brzezinski (1978).

5. For example, many schools don't have a department named political science (or government, or politics) but instead teach political science classes through a history or social sciences or general education department.

6. We included accredited schools that are graduate only (i.e., the Claremont Graduate University) and treated distinct political-science-related departments at the same university as different schools (i.e., Harvard University's Department of Government and Kennedy School of Government).

7. The following students (and a few former students!) provided invaluable help (much of it as volunteers), and have my profound thanks: Mallory Homewood, Kayvan Chinichian, Alex Finch, Alyson Pietrowski, Jimmy Sotelo, Leah Coleman, Alex Cunny, Christine Stradford, Manuel Reynoso, Maggie Stone, Janelle Little, Rob Binning, Andy Hillier, Doug Johns, Taylor Roschen, Sarah Prince, Lauren Schneider, Danielle Kennedy.

8. We identified departments from: CollegeBoard (2006).

9. We defined political theory broadly. For example, it included any classes in the history of political thought and classes in American political thought, IR Theory, and public administration theory, as well as classes on themes like justice in politics. We excluded classes/individuals whose interest appeared to be in "formal" theory-that is, in statistical modeling.

10. I decided to exclude Positive Political Theory on the grounds that scholars who are doing formal modeling and scholars who are commenting on and producing normative political theory are engaged in clearly distinct activities. That both are called "theory" is an accident of disciplinary history.

11. Four thousand eight hundred fifty-three by e-mail, 291 by U.S. Mail.

12. I also sent 35 U.S. Mail invitations addressed generically to the department chair at schools where no individual faculty members could be identified. None of those invitations received a reply.

13. Actually, six additional invitees identified themselves as ineligible and then completed the survey anyway. Since it is not possible to identify and remove their responses, I have counted them as recipients and participants. 
14. These are the people we initially identified as theorists, minus the people in that group whose invitations were returned as undeliverable, minus the people in that group who identified themselves as ineligible, plus the people in the couldn't-rule-them-out category who responded and thereby identified themselves as theorists.

15. See APSA Survey of Political Science Departments 2000-2001 (APSA 2001).

16. During 2009, the APSA sponsored a survey, conducted by Prof. Vicki Hesli at the University of Iowa, on this topic. The APSA is also conducting a separate survey to update the Survey of Political Science Departments.

17. Because the survey sample and the sample that the APSA statistics are based on overlap to an unknown degree, I was not able to come up with a method of assessing the statistical significance of the differences between the two sets of data.

18. See the National Science Foundation (2006). See revised Table $3 a$.

19. On this issue see Ferguson, K. (2010). "Subfield Hockey: A Reaction to Matthew Moore's National Survey of Political Theorists." PS: Political Science \& Politics 43(02): 275-277.

20. For an excellent, recent overview of the literature, see March (2009).

21. See Joel Kassiola's thoughtful discussion of the advantages and disadvantages of using secondary texts (2007).

22. Moore, M. J. (2010). "Political Theory Today: Results of a National Survey." Ibid. 43(2): 265-272.

23. For a follow-up study on the impact of the Wahlke Report see Ishiyama (2005).

24. For an overview of publication on teaching and learning within political science, see Hamann et al. (2009).

25. For an overview of some of the early literature, see Hutchings et al. (2002).

26. Notably Julian et al. (1991), Fox and Keeter (1996), Kelly and Klunk (2003), Smoller (2004), Deardorff (2005), Deardorff and Folger (2005), Deardorff and Posler (2005), Hill (2005), Campbell (2007), Deardorff (2007), Ishiyama and Breuning (2008).

27. See the literature cited in Note 26.

28. See Ishiyama and Breuning (2008).

\section{References}

Ackelsberg, Martha. 2010. "Political Theory Today: Who's Teaching What to Whom? Some Reflections." PS: Political Science \& Politics 43(02): 279-282.

American Political Science Association. 2001. APSA Survey of Political Science Departments 2000-2001. Washington, DC.

American Political Science Association. 2007. Directory of Political Science Faculty \& Programs 2007-2008. Washington, DC.

Asal, Victor. and Elizabeth L. Blake. 2006. "Creating Simulations for Political Science Education." Journal of Political Science Education 2(1): 1-18.

Barber, Benjamin R. and Richard Battistoni. 1993. "A Season of Service: Introducing Service Learning into the Liberal Arts Curriculum." PS: Political Science and Politics 26(2): 235-240.

Barberio, Richard P. 2004. "The One-Armed Bandit Syndrome: Overuse of the Internet in Student Research Projects." PS: Political Science \& Politics 37(2): 307-311.

Botsch, Carol S. and Robert E. Botsch. 2001. "Audiences and Outcomes in Online and Traditional American Government Classes: A Comparative Two-Year Case Study." PS: Political Science and Politics 34(1): 135-141.

Brock, Kathy L. and Beverly J. Cameron. 1999. "Enlivening Political Science Courses with Kolb's Learning Preference Model." PS: Political Science and Politics 32(2): 251-256.

Campbell, Kenneth J. 2007. "Assessment Advice for Beginners." PS: Political Science \& Politics 40(1): 99-99.

Carter, Lief H. and Jean Bethke Elshtain. 1997. "Task Force on Civic Education Statement of Purpose." PS: Political Science and Politics 30(4): 745. 
Clawson, Rosalee A., Rebecca E. Deen, and Zoe M. Oxley. 2002. "Online Discussions across Three Universities: Student Participation and Pedagogy." PS: Political Science and Politics 35(4): 713-718.

CollegeBoard. 2006. 2007 College Handbook. New York: The College Board.

Deardorff, Michelle D. 2005. "Assessment Through the Grassroots: Assessing the Department via Student Peer Evaluation.” Journal of Political Science Education 1(1): 109-127.

Deardorff, Michelle D. 2007. "Methods of Effectively Leveraging Departmental Assessment Programs." PS: Political Science and Politics 40(1): 100-101.

Deardorff, Michelle D. and Paul J. Folger. 2005. "Assessment that Matters: Integrating the "Chore" of Department-Based Assessment with Real Improvements in Political Science Education." Journal of Political Science Education 1(3): 277-287.

Deardorff, Michelle D., Kerstin Hamann and John Ishiyama, eds. 2009. Assessment in Political Science. Washington, DC: American Political Science Association.

Deardorff, Michelle D. and Brian D. Posler. 2005. "The Mission-Driven Department: Benefits of Departmental Assessment." PS: Political Science and Politics 38(2): 273-276.

Dolan, Kathleen. 2008. "Comparing Modes of Instruction: The Relative Efficacy of On-Line and In-Person Teaching for Student Learning." PS: Political Science \& Politics 41(2): 387-391.

Dolowitz, David P. 2007. "The Big E: How Electronic Information Can Be Fitted Into the Academic Process.” Journal of Political Science Education 3(2): 177-190.

Driver, Darrell, Kyle Jette, and Leonard Lira. 2008. "Student Learning Identities: Developing a Learning Taxonomy for the Political Science Classroom." Journal of Political Science Education 4(1): 61-85.

Ernst, Howard R. and Tracy L. Ernst. 2005. "The Promise and Pitfalls of Differentiated Instruction for Undergraduate Political Science Courses: Student and Instructor Impressions of an Unconventional Teaching Strategy." Journal of Political Science Education 1(1): $39-59$.

Ferguson, Kennan. 2010. "Subfield Hockey: A Reaction to Matthew Moore's National Survey of Political Theorists." PS: Political Science \& Politics 43(02): 275-277.

Fox, J. Clifford and Scott Keeter. 1996. "Improving Teaching and Its Evaluation: A Survey of Political Science Departments." PS: Political Science and Politics 29(2): 174-180.

Fox, Richard L. and Shirley A. Ronkowski. 1997. "Learning Styles of Political Science Students." PS: Political Science and Politics 30(4): 732-737.

Freie, John F. 1997. "A Dramaturgical Approach to Teaching Political Science.” PS: Political Science and Politics 30(4): 728-732.

Garson, G. David. 1998. "Evaluating Implementation of Web-Based Teaching in Political Science." PS: Political Science and Politics 31(3): 585-590.

Gunnell, John G. 2006. "The Founding of the American Political Science Association: Discipline, Profession, Political Theory, and Politics." American Political Science Review 100(4): 479-486.

Hajjar, Sami G. and Steven Brzezinski. 1978. "Teaching Normative Political Theory: A Nationwide Faculty Survey." Teaching Political Science 5(3): 295-306.

Hamann, Kerstin, Philip H. Pollock, and Bruce M. Wilson. 2009. "Who SoTLs Where? Publishing the Scholarship of Teaching and Learning in Political Science." PS: Political Science \& Politics 42(04): 729-735.

Hill, Jeffrey S. 2005. "Developing a Culture of Assessment: Insights from Theory and Experience." Journal of Political Science Education 1(1): 29-37.

Hutchings, Pat, Chris Bjork, and Marcia Babb. 2002. "The Scholarship of Teaching and Learning in Higher Education: An Annotated Bibliography." PS: Political Science and Politics 35(2): 233-236.

Ishiyama, John. 2005. "Examining the Impact of the Wahlke Report: Surveying the Structure of the Political Science Curricula at Liberal Arts and Sciences Colleges and Universities in the Midwest." PS: Political Science and Politics 38(1): 71-75. 
Ishiyama, John and Marijke Breuning. 2008. "Assessing Assessment: Examining the Assessment Plans at 50 Political Science Departments." PS: Political Science \& Politics 41(1): 167-170.

Johnson, Jeffrey A. 2008. "On the Advantage and Disadvantage of History for Teaching Political Theory to Undergraduates." Journal of Political Science Education 4(3): 341-356.

Julian, Frank H., H. Chamberlain Don, and Robert A. Seay. 1991. "A National Status Report on Outcomes Assessment by Departments of Political Science." PS: Political Science and Politics 24(2): 205-208.

Kassiola, Joel. 2007. "Effective Teaching and Learning in Introductory Political Theory: It All Starts with Challenging and Engaging Assigned Readings.” PS: Political Science and Politics 40(4): 783-787.

Kelly-Woessner, April and Matthew Woessner. 2006. "My Professor is a Partisan Hack: How Perceptions of a Professor's Political Views Affect Student Course Evaluations." PS: Political Science and Politics 39(3): 495-501.

Kelly, Marisa and Brian E. Klunk. 2003. "Learning Assessment in Political Science Departments: Survey Results." PS: Political Science and Politics 36(3): 451-455.

Lawrence, Christopher N. and Michelle L. Dion. 2010. "Blogging in the Political Science Classroom." PS: Political Science \& Politics 43(01): 151-156.

March, Andrew F. 2009. "What Is Comparative Political Theory?" The Review of Politics 71: 531-565.

Miller, Char R. 2000. "Drawing Out Theory: Art and the Teaching of Political Theory." PS: Political Science and Politics 33(2): 213-218.

Moore, Matthew J. 2010. "Political Theory Today: Results of a National Survey." PS: Political Science and Politics 43(2): 265-272.

Mott, Margaret 2008. "Passing Our Lives through the Fire of Thought: The Personal Essay in the Political Theory Classroom." PS: Political Science \& Politics 41(1): 207-211.

National Science Foundation. 2006. "Survey of Earned Doctorates." < http://www.nsf.gov/ statistics/srvydoctorates/sedreporting/>. (April 20, 2010).

Novkov, Julie and Scott Barclay. 2010. "Lesbians, Gays, Bisexuals, and the Transgendered in Political Science: Report on a Discipline-Wide Survey." PS: Political Science \& Politics 43(1): 95-106.

Pollock, Philip H. and Bruce M. Wilson. 2002. "Evaluating the Impact of Internet Teaching: Preliminary Evidence from American National Government Classes." PS: Political Science and Politics 35(3): 561-566.

Roberts, Matthew. 2008. "Adventures in Podcasting." PS: Political Science \& Politics 41(3): 585-593.

Robinson, Andrew M. and Karen Schlegl. 2005. "Student Use of the Internet for Research Projects: A Problem? Our Problem? What Can We Do About It?" PS: Political Science \& Politics 38(2): 311-315.

Smoller, Fred. 2004. “Assessment Is Not a Four-Letter Word.” PS: Political Science and Politics 37(4): 871-874.

Strauss, Leo. 1988. Persecution and the Art of Writing. Chicago: University of Chicago Press.

Taylor, Mark Zachary. 2009. "Podcast Lectures as a Primary Teaching Technology: Results of a One-Year Trial." Journal of Political Science Education 5(2): 119-137.

Wahlke, John C. 1991. "Liberal Learning and the Political Science Major: A Report to the Profession." PS: Political Science and Politics 24(1): 48-60.

Wilson, Bruce M., Philip H. Pollock, and Kerstin Hamann. 2006. "Partial Online Instruction and Gender-Based Differences in Learning: A Quasi-Experimental Study of American Government." PS: Political Science and Politics 39(2): 335-339.

Woessner, Matthew. and April Kelly-Woessner. 2009. "I Think My Professor is a Democrat: Considering Whether Students Recognize and React to Faculty Politics." PS: Political Science and Politics 42(2): 343-352. 